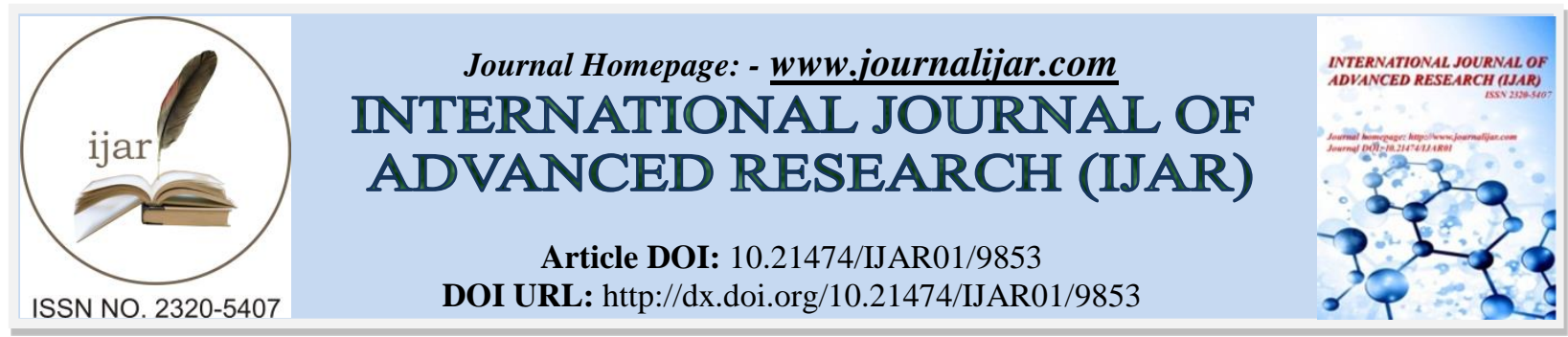

RESEARCH ARTICLE

\title{
GROWTH OF INFORMAL EDUCATION SECTOR IN BANGLADESH: A CASE STUDY ON BARISHAL CITY CORPORATION AREA.
}

Md. Ohidur Zaman ${ }^{1}$, Dr. Tareq Mahamud Abir ${ }^{1}$ and Farjana Afroz ${ }^{2}$.

1. Assistant Professor, Department of Sociology, University of Barishal, Bangladesh.

2. Lecturer, Department of Sociology, University of Barishal, Bangladesh.

\section{Manuscript Info}

Manuscript History

Received: 08 August 2019

Final Accepted: 10 September 2019

Published: October 2019

Key words:-

Formal education, Informal education,

Shadow education system.

\section{Abstract}

The study aimed to identify the factors which are associated with the growth of the informal education sector in Bangladesh. The Barishal city, a southern rising city of Bangladesh was selected as a study area. An explorative research design was chosen for the study. A total of 100 respondents (students) participated in the study and two FGDs (Parents $\&$ Teacher) taken for both quantitative and qualitative data collection. Empirical data refers to that in the study area informal educational institutions are rising and functioning as a shadow education system. Most of the students are dependent on informal education institutions because they believe that formal institutions are not capable to provide satisfactory services. The major factors which are responsible for fall of the formal education sector are- lack of attention of the authority, big student size in the classroom, a small number of teachers at the formal institution, unjustified syllabus, teachers' intention to not provide quality education in the classroom due to low salary, etc. Moreover, psychologically students and parents are dependent on the informal education system to get desirable success in the public examination where the teachers are interested to earn extra money by providing extra time and care in the informal educational system.

Copy Right, IJAR, 2019,. All rights reserved.

\section{Introduction:-}

The economy of Bangladesh is experiencing new dissension and moving towards the status of a middle-income country. To ensure sustainable economic development there is no alternative to educated manpower. Thus the government of Bangladesh with the help of the private sector and NGOs trying to provide quality education to accept upcoming challenges. There are various types of education systems existing here such as Bangla Medium, English Medium, Arabic Medium, Vocational, etc. Despite various education systems, the private tuition market rises in a vast extant and works as the shadow education system. Many research outcomes represent that the shadow education system enables students to achieve expectable results in public examinations because this private tuition market fallows the same curriculums like public education (Bray, 1999, 2006; Bray \& Kwok, 2003; Kwok, 2001). Students from both the school level and undergrad level highly depend on the private tuition market. Moreover, for admission to University a massive private coaching center rises in this country.

Corresponding Author:-Md. Ohidur Zaman.

Address:-Assistant Professor, Department of Sociology, University of Barishal, Bangladesh. 
Informal education is the learning process that individuals can acquire outside of the formal institution. It is the wise, respectful and spontaneous process of cultivating learning which works through conversation, and the exploration and enlargement of experience (Jeffs 2011). According to some research reports, both social and educational factors are responsible for the extensive acceptance of private tutoring (Heung-ju, 2006). The private tuition market has key social and economic consequences on the present education provisions (Bray, 1999). The evidence from a Korean study revealed that poorer formal school quality ascends demand for private tutoring significantly (Kim et. al, 2004). In Turkey, competitive university entrance examinations stimulated the growth of the private tuition market (Tansel \& Bircan, 2004). Developed country like Canada, shadow education system is gradually transforming to independent private learning centers because of high public demand (Aurini \& Davies, 2003). Although in many countries the private tuition market works as the supplementary system which increases the capability of students to achieve success in the formal sector, in the case of Bangladesh it is proved that the formal sector is unable to meet the minimum classroom teaching quality. Sometimes this shadow education system generates dysfunction and social inequality among the students (Ahmed \& Nath, 2005; Nath, 2008). Recently Government of Bangladesh published official gazettes with rules and regulations to control the massive private tuition market.

This study discloses all the major factors that are liable for influencing the rise of informal education in the Barishal city of Bangladesh. Secondly, this study would help to find out the lacking of the formal education sector. Thirdly, this study would help to mark out the offerings of the informal education sector. Fourthly, the findings of the study would help the education policy planners to make suitable policy measures for quality education in Bangladesh. Finally, this study would facilitate the proper implementation of policies to improve the quality of education in Bangladesh. The main objective of the study is to identify the factors lying behind the rise of the informal education sector in Barishal city of Bangladesh. The specific objectives of the study are:

1. To compare the present scenario of formal and informal education.

2. To find out the factors which play crucial roles in raising the informal education sector.

In this study, the researchers considered students who are in class 9-12 and go to both school/college and coaching center/private tuition. Whose child is a student of class 9-12 and go to both school/college and coaching center/private tuition are considered as a guardian in this study. The person who is currently working in both school/college and coaching center/private tuition is considered as a teacher in this study. Mainstream educational institutions such as schools, colleges are considered as formal educational institutions. There are many kinds of informal educational institutions in Bangladesh. But for this study, the researchers considered coaching centers and private tuitions as informal educational institutions.

\section{Methodology:-}

As this research work is an explorative composition and explorative research work highly supports mixed methods, the researcher has used a mixed-method research approach for data collection and analysis. Barishal City Corporation area was purposively selected as a study area. The researcher proposed that the unit of analysis of his study would be multi-unit analysis. The first unit includes students of class 9-12 who attend both formal and informal education institutions in the Barishal metropolitan area. The second unit includes their guardians and the third unit is the teachers of the selected students. All of the students both male and female of the study area who read in class 9 to 12 were the population of the study. In this study, the total population can't be tracked accurately and there is no such previous data. Among various non-probability sampling techniques 'quota sampling' is suitable for the study. The respondents must have some obvious characteristics such as the students must go to both the formal and informal education institute, 9-12 years of schooling, a resident of the Barisal metropolitan area, a student of selected institutions, etc. The sample is selected from a location convenient to the study, and whenever a student with the relevant characteristic is seen the student is asked to participate in the study. The process continues until the researcher has been able to contact the required number of respondents. 66 male and 34 female students from both secondary and higher secondary levels, 1 group of guardians of those selected students and 1 group of teachers from secondary and higher secondary levels were selected as sample. As the group should be neither too large nor too small because this can impede upon the extent and quality of the discussion, approximately six to fifteen people were selected as the optimal number for every discussion group. Survey data were collected by semi-structured questionnaire and FGDs were conducted by guide questionnaires. Moreover, all the primary data were collected by face to face interaction. SPSS program has been used for analyzing and processing quantitative data. Qualitative data has been processed manually. 


\section{Data Analysis and Result Discussion:- Quantitative Data Analysis:}

Among surveyed samples, $66 \%$ are male and $34 \%$ are female. This represents a higher presence of male students. Table- 01 shows the distribution of the respondents by age. $9 \%$ of the respondents' age below $15,13 \%$ age between $15-16,45 \%$ age between $17-18,14 \%$ age between $19-20$ and only $2 \%$ age above 20 . This data represents most of the participant's age is in between 15-18 group. Similarly, the same table represents the distribution of the respondents by education level. $21 \%$ of the respondents are in class 9,29\% are in class 10,28\% are in Class $11,22 \%$ are in Class 12. This table represents that every class has a similar kind of participation rate.

Table 01:-Gender, Age, and Level of Classes of the Respondents

\begin{tabular}{|l|l|}
\hline Gender & Percentage \\
\hline Male & 66.0 \\
\hline Female & 34.0 \\
\hline Total & 100.0 \\
\hline Age & \multicolumn{2}{|l|}{} \\
\hline Below 15 & 9.0 \\
\hline $15-16$ & 30.0 \\
\hline $17-18$ & 45.0 \\
\hline $19-20$ & 14.0 \\
\hline Above 20 & 2.0 \\
\hline Total & 100.0 \\
\hline Level of Classes & \\
\hline Class 9 & 21.0 \\
\hline Class 10 & 29.0 \\
\hline Class 11 & 28.0 \\
\hline Class 12 & 22.0 \\
\hline Total & 100.0 \\
\hline
\end{tabular}

Source: Field data 2019

Table-02 demonstrates the distribution of the respondents by the school/college-going rate regularly. $53 \%$ of the students go to school/college regularly, whereas $47 \%$ don't go to school/college regularly. This represents almost half of the respondents don't go to formal educational institutions regularly. Again, $80 \%$ of the respondents go to coaching regularly, whereas $20 \%$ don't. This represents most students go to coaching/ informal educational institutions regularly. In the case of teachers' attendance at educational institutions, $72 \%$ of students said that teachers take classes regularly, whereas $28 \%$ said teachers don't take classes regularly in their schools \& colleges. Whereas, $94 \%$ of students said that teachers take classes regularly, whereas $6 \%$ said teachers don't take classes regularly in their coaching centers. Thus, the teacher's rate of taking classes is much higher in informal institutions than formal institutions. The number of available classrooms is also influential factors for educational institutions and $54 \%$ of students said the number of the classroom is sufficient, whereas $46 \%$ said that insufficient informal institutions. In informal institutions like coaching centers, $74 \%$ of students said the class number is sufficient, whereas $26 \%$ said insufficient. The same table represents that $59 \%$ of students said that class duration is sufficient in the formal institutions on another hand $87 \%$ of students said that class duration is sufficient in informal institutions. It means that students get more time to lean in a specific subject from informal education. Therefore, they chose an informal institution as a shadow education system.

Table 02:-Comparison of the factors between Formal and Informal Educational Institutions

\begin{tabular}{|l|l|l|l|}
\hline Factors & Description & $\begin{array}{l}\text { Formal } \\
\text { Educational } \\
\text { Institute (\%) }\end{array}$ & $\begin{array}{l}\text { Informal } \\
\text { Educational } \\
\text { Institute (\%) }\end{array}$ \\
\hline \multirow{2}{*}{ Attendance Rate } & Regular & 53 & 80 \\
\cline { 2 - 4 } & Irregular & 47 & 20 \\
\hline \multirow{2}{*}{ Teachers' Class Attendance Rate } & Regular & 72 & 94 \\
\cline { 2 - 4 } & Irregular & 28 & 6 \\
\hline \multirow{2}{*}{ Number of Class Room } & Sufficient & 54 & 74 \\
\cline { 2 - 4 } & Insufficient & 46 & 26 \\
\hline
\end{tabular}




\begin{tabular}{|l|l|l|l|}
\hline \multirow{2}{*}{ Duration of Class } & Sufficient & 59 & 87 \\
\cline { 2 - 4 } & Insufficient & 41 & 13 \\
\hline \multirow{2}{*}{$\begin{array}{l}\text { Ability to Complete Syllabus within the } \\
\text { Time }\end{array}$} & Capable & 46 & 81 \\
\cline { 2 - 4 } Teachers' cooperation & Not Capable & 54 & 19 \\
& Very Cooperative & 13 & 27 \\
\cline { 2 - 4 } & Cooperative & 45 & 53 \\
\cline { 2 - 4 } & Neutral & 42 & 20 \\
\hline \multirow{5}{*}{ Study Environment } & Very Pleasant & 60 & 53 \\
\cline { 2 - 4 } & Pleasant & 13 & 33 \\
\cline { 2 - 4 } & Unpleasant & 20 & 7 \\
\cline { 2 - 4 } & Very unpleasant & 7 & 7 \\
\hline \multirow{4}{*}{ Management } & Very strong & 13 & 1 \\
\cline { 2 - 4 } & Strong & 40 & 53 \\
\cline { 2 - 4 } & Not Strong nor Weak & 27 & 40 \\
\cline { 2 - 4 } & Weak & 7 & 6 \\
\cline { 2 - 3 } & Very weak & 13 & 1 \\
\hline
\end{tabular}

Source: Field data 2019

Field data refer that in the formal institutions, $46 \%$ of students said that teachers can finish the syllabus properly in time whereas in informal institutions $81 \%$ of students said that teachers can finish the syllabus properly in time. Hence, students go for informal institutions after the end of the teaching in the formal intuition to complete their syllabus. Respondents of the study get more cooperation from the teacher from the informal institutions. However, according to field data study environment is more or less similar in both formal and informal institutions. Moreover, in the case of management of the institution, the formal institution is comparatively better than informal institutions.

\section{Qualitative Data Analysis:}

In this study, the researcher could find out the major factors associated with the rise of the informal education sector in Barisal city. Evaluating the data the researchers came to these findings:

Nowadays, most often formal education institutions can't offer their full potential. Students and their parents think that school/college offer way less than what they are supposed to offer. That's why a large number of students now prone to not going to school/college regularly. Teachers also have less attendance in school/college classes. Sometimes the class number and duration are not sufficient for an effective class. That's why sometimes teachers can't finish the syllabus in time. Teachers in school/college aren't uncooperative but they can be more cooperative. The study environment is less enjoyable for students in school/college now. Without that the management and regulation body is less active and strict. There is a huge space for teachers' improvement in teaching methods. Coaching centers provide a better service in most aspects compared to school/college. Most of the students have a higher attendance rate here. Teachers have also a higher attendance rate. Coaching centers have sufficient class number and time. That's why teachers can finish the syllabus properly in time. Teachers' cooperation is better compared to school/college. Coaching centers don't have a better study environment as they have less classroom space. Coaching centers have strong management bodies which have better integration with students and teachers. Without that teachers have a better teaching method here. In most cases, coaching centers provide a better outcome compared to school/college. Coaching centers fulfill the demand where school/college fails to provide a quality service. Though coaching centers have some limitations too, it performs better in most scenarios compared to school/college. The coaching center is a short term solution for a long term problem. That's why the researcher also puts some recommendations to better the services of school/college.

\section{Conclusion and Recommendations:-}

The entire study explains the existing situation in formal and informal education institutions including their services, offerings, lacking, and service quality and so on. This study draws some possible recommendations from students, teachers, and parents like reducing class size, school/college-based coaching, eliminating corruption, etc. Furthermore, hopefully, this research and its findings will help policymakers to understand major challenges and take proper actions accordingly. The findings of this study recommend:

1. Reduced class size for a better study environment in school/college. The student number should not exceed 50 by any means.

2. Class numbers and duration can be increased in school/college. 
3. School/college must have a strong management body that will be able to regulate fully.

4. The teaching method should be improved in school/college. Education ministry can launch a teaching method development program.

5. Extra study materials can be supplied in school/college classes as they help students.

6. Teacher's salaries should be improved

7. Some weak students will always need special care. Coaching can be limited only to them. Weak students can be determined by the exam result.

8. Special laws/regulations can be passed to stop the coaching business.

9. The question paper should come from another school/college and no teacher should have access to them. This will stop teachers to provide illegal benefits to students.

10. Exam paper can be examined by teachers of other classes randomly or teachers of other institutions. This will limit the illegal benefits in school/college.

11. A regularity monitor board can be established in school/college to monitor teachers' class performance and suggest reward or punishment accordingly.

\section{References:-}

1. Bray, M. (2006). Private supplementary tutoring: Comparative perspectives on patterns and implications. Compare, 36(4), 515-530.

2. Bray, M., \& Kwok, P. (2003). Demand for private supplementary tutoring: conceptual considerations, and socio-economic patterns in Hong Kong. Economics of Education Review, 22(6), 611-620.

3. Bray, T. M. (1999). The shadow education system: Private tutoring and its implications for planners. UNESCO International Institute for Educational Planning..

4. Davies, S., \& Aurini, J. (2003). Homeschooling and Canadian educational politics: Rights, pluralism and pedagogical individualism. Evaluation \& Research in Education, 17(2-3), 63-73.

5. Heung-ju, K. (2006). Korea's Obsession with Private Tutoring. Asian Network of Training and Research Institutions in Educational Planning (ANTRIEP) Newsletter, 11(1), pp. 11-17

6. Jeffs, T. (2001). Historical perspectives on informal. Principles and practice of informal education: Learning through life, 34.

7. Kim, E., Nam, D. I., \& Stimpert, J. L. (2004). Testing the applicability of Porter's generic strategies in the digital age: A study of Korean cyber malls. Journal of Business Strategies, 21(1).

8. Kwok, P. (2001). Local knowledge and value transformation in East Asian mass tutorial schools. International Education Journal, 2(5), 86-97.

9. Nath, S. R. (2008). Private supplementary tutoring among primary students in Bangladesh. Educational Studies, 34(1), 55-72.

10. Reaz Ahmed, S., Deb Nath, S. K., \& Wahhaj Uddin, M. (2005). Optimum shapes of tire-treads for avoiding lateral slippage between tires and roads. International Journal for numerical methods in Engineering, 64(6), 729-750.

11. Tansel, A., \& Bircan Bodur, F. (2004). Private tutoring expenditures in Turkey. 